\title{
The method of complex evaluation of management in the sphere of housing and communal services
}

\author{
Svetlana Okhotina ${ }^{1, *}$, Peter Kukhtin ${ }^{2}$, and Lyubov Manukhina ${ }^{3}$ \\ ${ }^{1}$ Vyatka State University», Moskovskaya str., 36, Kirov, 610000, Russia \\ ${ }^{2}$ Financial University under the government of the Russian Federation, Leningrad pr., 49, Moscow \\ 125993, Russia \\ ${ }^{3}$ Moscow State University of Civil Engineering, Yaroslavskoe shosse, 26, Moscow, 129337, Russia
}

\begin{abstract}
Many researchers considered the quality of management, but the definition of "quality control" in the literature is quite rare. The author's definition of this concept, whose distinctive features are as follows: management is considered as a system, and its quality is determined by the quality of the elements of the system; management is of high quality, if not only provides function, but also the development of the facility; the quality of management is measured by customer satisfaction. The study authors of market relations in the sphere of housing and communal services helped to define the modern model of management of the industry of housing and communal services, which involves the preservation of state regulation and control and the bringing to market of private operators. Identified the need for further sustained efforts to implement the new economic relations in the system of housing and communal services at all levels of government, which requires further improvement of management. Based on the authors analysis of the methods of evaluation of activities of management companies found that despite their diversity they all have several disadvantages, the main of which is the lack of standard indicators by which to judge to what extent the housing managers of the organization implement the adopted programme. Therefore, the author proposes two sets of criteria (representing the result of control and management efficiency), which will be monitored and evaluated the quality management of the organization.
\end{abstract}

\section{Introduction}

The main objective of assessing the quality of management is to identify how the characteristics of the selected governance model meet the requirements of consumers. We believe that the basis of assessment of the quality of governance should be underpinned by the following principles:

- $\quad$ customer orientation (the need for analysis of customer satisfaction services);

\footnotetext{
*Corresponding author: ohotina@list.ru
} 
- scientific validity (the evaluation is based on the science-based provisions, methods and approaches);

- the complexity of quality evaluation (judgment about the quality control must be multifaceted, taking into account the characteristics and properties that expresses certain aspects of the quality of this activity);

- the system (determined by the quality of the elements included in the control system (purpose, objectives, principles, methods, technologies, etc.);

- the combination of quantitative and qualitative analysis (applied both quantitative and qualitative methods and evaluation);

- continuity and phasing of the implementation of the assessments (the assessment should be a continuous process and to be present at all stages of managerial work);

- continuous self-assessment of the management of the organization (the dynamics of the factors of external and internal environments, the need for timely detection of changes and change management activities taking into account the received information);

- improvement (identifying strengths and weaknesses of management and improvement opportunities of the organization).

\section{Methods}

Evaluation of the quality of management of housing and communal services cannot be reduced only to a certain function performed by the authorized administrative bodies, and is a complex group action, which is attended by representatives of regional Executive authorities of the region, municipal authorities and entities of private business [1-8]. Therefore, the quality of management of housing and communal services should be considered from the standpoint of:

- bodies of state and municipal authorities (preservation and development of housing and communal services);

- business (breakeven operation of the enterprises);

- $\quad$ population (high quality services on the basis of socially-oriented tariffs).

\section{Results}

This paper presents a comprehensive approach to assessing the quality of management of housing and communal services (Figure1).

Currently, when assessing the quality of governance are mainly used quantitative indicators on the economic and financial activities. The value of economic and financial information is not in doubt and remains a key indicator for investors and government. However, only quantitative indicators for assessing the quality of management is not sufficient [5-10].

The main subject of ensuring the quality of housing services that meet the requirements of the standards, acts as the managing organization. In this connection, scientific and practical interest is the evaluation of the activities of managing organizations from the standpoint of development of effective managerial decisions.

\section{Discussion}

The analysis of the activities of the management companies offered by the Fund of assistance to reforming of housing and communal services, sponsored by I. Abercelyn; V. Korobko; P. Zhadko [1-3], 


\begin{tabular}{|c|c|}
\hline \multicolumn{2}{|c|}{ 1. Evaluation of management of housing and communal services } \\
\hline $\begin{array}{l}2 \text { Assessment of } \\
\text { regional level } \\
\text { management }\end{array}$ & $\begin{array}{l}\text { 2.1 Analysis and development of housing in the region (methods a } \\
\text { retrospective structural and comparative analysis); } \\
\text { 2.2 Analysis of organizational forms of management utilities } \\
\text { (methods a retrospective, comparative analysis); } \\
\text { 2.3 Analysis of the regional target programs (descriptive method); } \\
\text { 2.4 Analysis of regional standards of cost housing-utilities (methods, } \\
\text { comparative, structural, factor analysis); } \\
\text { 2.5 Analysis of experience with public-private partnership in the RF } \\
\text { subjects (descriptive method); } \\
\text { 2.6 analysis of the use of public-private partnerships in the region } \\
\text { (methods a descriptive and comparative analysis); } \\
\text { 2.7 Analysis and dissemination of experience of application of } \\
\text { innovative technologies in housing (methods a descriptive, } \\
\text { comparative analysis). }\end{array}$ \\
\hline $\begin{array}{l}3 \text { Evaluation of } \\
\text { municipal management } \\
\text { level }\end{array}$ & $\begin{array}{l}\text { 3.1 analysis of the status and development of housing in the } \\
\text { municipality (methods a retrospective structural and comparative } \\
\text { analysis); } \\
\text { 3.2 analysis of the implementation of legal acts of the Russian } \\
\text { Federation and RF subject (descriptive method); } \\
\text { 3.3 Analysis of municipal programs of development of housing } \\
\text { (descriptive method); } \\
\text { 3.4 Analysis of experience in implementation of investment projects } \\
\text { (methods of comparative analysis); } \\
\text { 3.5 Analysis of experience of introduction of resource-saving } \\
\text { technologies (methods a retrospective and comparative analysis); } \\
\text { 3.6 analysis of the readiness of the housing stock for the winter } \\
\text { (descriptive method) } \\
\text { 3.7 the Analysis of work of management companies }\end{array}$ \\
\hline $\begin{array}{l}4 \text { Evaluation of } \\
\text { management in } \\
\text { organizations of } \\
\text { housing and communal } \\
\text { services }\end{array}$ & $\begin{array}{l}\text { 4.1 analysis of the economic and financial condition of the enterprise } \\
\text { (methods, comparative, structural, factor analysis); } \\
\text { 4.2 Analysis of quality of services (method of comparative analysis, } \\
\text { survey, questionnaire); } \\
\text { 4.3 Analysis of customer satisfaction (survey, questionnaire) }\end{array}$ \\
\hline
\end{tabular}

Fig. 1. The evaluation Method of management in the sphere of housing and communal services.

Effective innovative projects in the field of nanobiotechnology may be offered an unlimited number. Economic efficiency of this translational motion in a predetermined direction nanobiotechnological obvious. Socio-economic essence of nanoeconomics will define nanotechnology and nanobiotechnology - biotechnology, nanobiotechnology and technology that resemble natural ones. In nanobiotechnological format emerging new socio-economic and political realities, capable in the shortest possible time to overcome the technology gap and to ensure Russia's sustainable economic development. It is to revive Russia's traditional industries - pharmaceutical, textile, light, etc., to create a diversified agro-, forest - and neftegazopromyshlennyy clusters (centres of innovative development of regions) based on nanobiotechnological approach, which can play the role of an effective catalyst of innovative change and regional economic growth. Such biocluster using a deep and wasteless processing technology of biomass and wastes of various industries in the 
import-substituting products with high added value, will have strategic importance for antirecessionary dynamics of the economy of our country.

Value creation at business bioklaster occurs in several stages. In the world today, especially the importance of innovative research in the field of bioenergy, in particular, work on the creation of alternative fuels. Real steps in this direction have already been taken by our scientists of JSC "Corporation "Biotechnology", which has developed an enzymatic process of obtaining second generation biofuel - biobutanol from renewable non-food sources of raw materials (sawdust, straw, peat). In fact, it is a way to create in Russia a full-fledged biofuel industry on the basis of the organization of $\mathrm{PBC}$ on the basis of plants hydrolysis and the alcohol industry. Today in Russia there are about 150 distilleries, production facilities are loaded by about $40 \%$.

According to various estimates in Russia, where up to 3 billion tons of renewable resource cellulose. And at the same time, $30-40 \%$ of wood is in "dump" that is not utilized and rot. Putrid biomass (waste wood, sawdust, etc.) absorbs the oxygen of the atmosphere and emit carbon dioxide. The use of technology enzymatic processing of wood waste will apply on a broad scale biofuels (a mixture of gasoline and biobutanol in different proportions), which will significantly reduce the level of harmful emissions into the atmosphere.

It is obvious that the Russian Federation has all competitive advantages for the development of nanobiotechnology: in Russia, where up to $25 \%$ of the world reserves of wood, estimated at 82 billion cubic meters, or 41 billion tons, $45 \%$ of world reserves of peat, more than 200 million hectares of fertile land, (which is $9 \%$ of global arable land and $3 \%$ of global grassland); huge acreage, and at the same time, approximately 41 million acres of empty fertile land. In Russia, the total stock of soil fertility is $20 \%$ of the world level; a thick layer of humus reaches $1.5 \mathrm{~m}$ and to create Nature, it took 15 thousand years. Russia, by definition, is designed to feed the whole world, or every fifth inhabitant of the Earth, with all their reserves of black soil [7].

Today's reality, however, is very sad. Over the past 10 years the rural population in Russia decreased by 1 million. Give some specific examples. If half a century ago in the Tomsk region was more than 15 thousand villages, today there are only 600 . In the Kostroma region, one third of settlements have become extinct and another third are settlements, where up to 10 people. Most of the villages of black earth inhabit up to 50 people, and if not radically change carried out in relation to village policy, after some 15 years, the village as such in Russia will disappear altogether. Note also that 100 years ago $85 \%$ of Russia's population were peasants. Today $75 \%$ of Russian population lives in cities, and the number of villagers is about 37 million people [271], with about 7 million people (i.e. $10 \%$ of the working population) are employed in the agricultural sector [2]. Today in agriculture are still present archaic technology, and wages below half of the average for the industry.

You should immediately begin the process of revival of the village through the creation of agro-industrial and biotechnological bioclusters. This will enable in the next 3-5 years to increase the number of people employed in the agrifood industry to $12-14 \%$ of the total working population of the Russian Federation, to create an average of 4 million new highly productive jobs with an average wage of 80-100 thousand rubles a month. There is good scientific potential, a fairly well developed agriculture, powerful and renewable natural resources. It is estimated that during the year in the Russian Federation is formed 773 million tons of agricultural waste, 350 million. tons of animal waste, 23 million tons of poultry waste, 220 million tons, crop waste, 30 million tons of waste processing industry. And all this - a potential raw material bioclusters [2-9]. Only processing 100 million tons of manure can produce up to 3.5 million tons of organic fertilizer per year, export prices will be revenue - more than $\$ 1$ billion a year. On the average farm, for example, is formed per 
day 100 tons of manure. And in the year that the company is obliged to pay the state 36.5 million rubles of environmental fines (According to the formation of the Russian Government No. 344 dated 12.06.2003). And the processing of manure generated on the farm for 1 year, the company will receive over 60 million [9].

Of the Russian Federation, thus, has a huge stock of the total biomass, which can be used in order to renewable bioenergy, and in a wide range of chemical-technological processes (biotechnology, nanobiotechnology). However, this powerful energy of the action potential, provided free by Nature, are not implemented in full, moreover, it threatens environmental safety, becoming a dangerous accumulation, storage and outdoor tanks, toxic substances, emissions of which cause irreparable damage to the environment, penetrating into the groundwater, the air, poisoning the soil.municipalities of different cities. Studies have shown that procedures for the assessment of management quality are not perfect and have flaws. It was established that despite their large number and have no standard criteria and indicators. The conclusion is made about necessity of development of uniform methodology for the assessment of quality management in organizations of housing and communal services.

The author's technique of an estimation of quality of management in organizations. The methodology consists of three groups of criteria:

- criteria for characterizing the result of control;

- criteria for characterizing the efficiency of management;

- criteria for characterizing the quality of control system components.

\section{Conclusions}

The estimation of quality of management of housing and communal services complex group action, which is attended by representatives of regional Executive authorities of the region, municipal authorities and entities of private business [7-14]. This paper presents a comprehensive approach to assessing the quality of management of housing and communal services, combining different subjects of management, using both quantitative and qualitative methods of research. This methodology is based on the following principles: orientation on the consumer; the scientific validity; comprehensive assessments of the quality of management; system; the combination of quantitative and qualitative analysis; continuity in the implementation of evaluations; constant self-control with the organization; improvement.

\section{References}

1. A. P. Biryukov, Housing Reform - finding ways and methods of increase of efficiency of management of the industry ("Yugo-Vostok-Service", Moscow, 2005)

2. A. Mottaeva, MATEC 73, 07020 (2016)

3. A.B. Mottaeva, A. Zheltenkov, I. Stukanova, S. Ryabichenko, S. Zhuk, MATEC 73, 07026 (2016)

4. An.B. Mottaeva, As.B. Mottaeva, International Journal of Applied Engineering Research 10- 23, (2015)

5. An.B. Mottaeva, As.B. Mottaeva, International Journal of Applied Engineering Research, 11- 9 (2016)

6. E. Stein, N. Taskaeva, E. Chibisova, Procedia Engineering 165, 1410-1416 (2016)

7. T. Miroshnikova, N. Taskaeva, MATEC 73, 123284 (2016)

8. A. Pimenova, S. Kuzmina, N. Morozova, A. Mottaeva, MATEC 73, 07018 (2016) 
9. L.V. Nikolova, D.G. Rodionov, A.B. Mottaeva, International Journal of Economics and Financial Issues 6(S3), 1-7 (2016)

10. A.I. Shlafman, Izvestija Irkutskoj gosudarstvennoj jekonomicheskoj akademii 2, 8-12 (2010)

11. I. Polyakova, E. Vasilyeva, Procedia Engineering, 165 (2016)

12. L.V. Nikolova, D.G. Rodionov, A.B. Mottaeva, International Journal of Economics and Financial Issues 6(S3), 1-7 (2016)

13. E. Stein, N. Taskaeva, E. Chibisova, Procedia Engineering, 165 (2016)

14. T. Miroshnikova, N. Taskaeva, MATEC 73, 07006 (2016) 